\title{
STUDY ON THE CONCENTRATE OF PROTEOLYTIC ENZYMES ENRICHED IN BROMELAIN AND ITS EFFECTS ON INTERMEDIATE AND EXTENSIVE BURNS
}

\author{
SILVIU ADRIAN MARINESCU ${ }^{1,2 \#}$, CĂTĂLIN GHEORGHE BEJINARIU ${ }^{2 *}$, ANA-MARIA \\ BOIANGIU ${ }^{2}$, DRAGOȘ GEORGESCU ${ }^{1,3 \#}$, ALICE BĂLĂCEANU ${ }^{1,4 \#}$, FLORENTINA \\ GHERGHICEANU $^{1,5}$, CARMEN GIUGLEA ${ }^{1,6}$ \\ I "Carol Davila” University of Medicine and Pharmacy, Faculty of General Medicine, 6 Traian Vuia Street, 020956, Bucharest, \\ Romania \\ 2 "Bagdasar-Arseni” Emergency Clinical Hospital, Department of Plastic and Reconstructive Surgery, 12 Berceni Road, \\ 041915, Bucharest, Romania \\ 3 “Sfântul Ioan” Emergency Clinical Hospital, 13 Vitan-Bârzești Road, 042122, Bucharest, Romania \\ 4 "Sfântul Ioan" Emergency Clinical Hospital, Department of Internal Medicine, 13 Vitan-Bârzești Road, 042122, Bucharest, \\ Romania \\ ${ }^{5}$ Department of Marketing and Medical Technology, 8 Eroii Sanitari Boulevard, 050474, Bucharest, Romania \\ 6 "Sfântul Ioan" Emergency Clinical Hospital, Department of Plastic and Reconstructive Surgery, 13 Vitan-Bârzești Road, \\ 042122, Bucharest, Romania
}

*corresponding author: drbejinariu@gmail.com

\# Authors with equal contribution.

Manuscript received: November 2018

\begin{abstract}
The present study aimed to highlight the effects of the enzymatic debridement (ED) with a concentrate of proteolytic enzymes enriched in bromelain (CPE-B) on intermediate and extensive burns including facial and upper limbs. In order to carry out the study, the therapeutic protocol recommended by the producer was used and, as an extension of the indications, CPE-B was applied in multiple stages in the case of extensive burns and those located at the level of the cephalic extremity and hands. ED with CPE-B has proven to be an effective and selective method, having a significant impact on reducing hospitalization time, as well as reducing treatment costs, improving post-burn scarring and finally improving the patients' degree of satisfaction.
\end{abstract}

\section{Rezumat}

Prezentul studiu evidențiază efectele pe care le exercită debridarea enzimatică prin utilizarea concentratului de enzime proteolitice îmbogăţite cu bromelaină (CPE-B) asupra arsurilor extensive în regiunea facială și la nivelul membrelor superioare. Realizarea studiului a permis implementarea protocolului clasic recomandat de producător, dar și extinderea indicațiilor acestuia prin aplicarea seriată a concentratului în cazul arsurilor extensive și a celor localizate la nivelul extremității cefalice și a mâinilor. Debridarea enzimatică cu CPE-B s-a dovedit o metodă eficientă și selectivă, având un impact semnificativ asupra reducerii timpului de internare, scăderii costului tratamentului, precum și asupra îmbunătătirii cicatricilor și gradului de satisfacție al pacienților.

Keywords: bromelain, protease, enzymatic debridement, burn treatment

\section{Introduction}

Early eschar removals within $48 \mathrm{~h}$ improve the outcome of burn wound treatment. The complexity of burn depth assessment within this time frame due to burn depth progression and late demarcation, as well as logistical reasons, sometimes postpone the ideal time of eschar removal, which may lead to additional injury and loss of viable dermis. In summary, the optimal technique for eschar removal should selectively remove non-viable burned tissue, achieve minimal blood loss, allow for optimal clinical wound bed evaluation and treatment decisions resulting in faster wound healing by means of conservative treatment or early surgical coverage by autologous skin grafting in order to improve aesthetic and functional outcome and thus the quality of life $[5,49]$. The choice of optimal technique is still a matter of debate [32]. Aside from the classical technique of surgical excision, various other techniques have been developed, applied and validated for burn eschar removal: hydrosurgery, maggot therapy, laser, collagenase based enzymatic gel treatment, special cautery systems and bromelain based enzymatic debridement (ED) $[1,10,15,17,20,29,36-38,40]$. 
There is increasing evidence that enzymatic debridement is a powerful tool to remove eschar in burn wounds, reducing blood loss [11], the need for autologous skin grafting and the number of wounds requiring surgical excision [9]. In addition, it has been shown that enzymatic debridement can reduce the rate of burn wound infection and the length of hospital stay, which is mainly due to early application and timely eschar removal $[6,21,38]$.

Proteases, the enzymes considered to be the most significant of all industrial enzymes, with annual sale of about 2.68 billion euros [30], are widely used in food, pharmaceutical and detergent industries [16]. Plant proteases, papain from Carica papaya, ficin from Ficus spp. and bromelain from pineapple plant (Ananas comosus) [14], have been gaining unique attention in the field of biotechnology and medicine due to their exploitable properties.

Bromelain is the proteolytic enzyme found in vegetable tissues like peel, stem, fruit and leaves of the Bromeliaceae family, including pineapple. The enzyme found in pineapple stem (EC 3.4.22.32) is sulphydrylic, and the sulphydryl group is essential to the proteolytic activity [3, 22]. The one found in pineapple fruit (EC 3.4.22.33) is an acid protein, and its isoelectric point is 4.6 , determined by isoelectric focusing. Irreversible conformational changes occur at $\mathrm{pH}$ values higher than 10.3 [22]. Some other minor cysteine endopeptidases (ananain, comosain) are also present in the pineapple stem bromelain among a complex mixture of different thiol-endopeptidases and other partially characterized components such as phosphates, glucosidases, peroxidases, cellulases, glycoproteins and carbohydrates, among others [26, 34].

The current study presents the authors' experience regarding the treatment of burns in the "BagdasarArseni” Emergency Clinical Hospital, describing in detail the therapeutic approach according to the particularities of the cases, the recommended surgical conduct, as well as the long-term postoperative monitoring - the removal of damaged tissue from wounds or second/third degree burns termed as ED in relation with scar quality. The study is limited to presenting the results obtained between 2009 and 2018, presenting the advantages and disadvantages of this modern therapeutic approach [38].

\section{Materials and Methods}

The present research included data obtained from the treatment of 256 patients admitted to the "BagdasarArseni” Emergency Clinical Hospital, Bucharest, Romania, from which 120 (Group 1) have been treated using a CPE-B enzymatic debridement and 136 underwent classical treatment by surgical excision (Group 2).

In terms of lesion topography, the present study provides an overview of the treatment of burns located at the level of the hand, upper and lower limbs, chest and facial regions. All subjects included in the study have given their informed, written consent and followed the principles of the Declaration of Helsinki. The study has been approved by the Ethical Committee of the "Bagdasar-Arseni" Emergency Clinical Hospital. All admitted patients with deep partial to full-thickness burns of the upper extremities not meeting exclusion criteria (Table I) underwent ED within the first $48 \mathrm{~h}$ after trauma, preferably accompanied by regional anaesthesia via brachial plexus blockage.

Table I

Applied CPE-B exclusion criteria

CPE-B contraindications as listed by manufacturer [ 53

Hypersensitivity to the active substance, to pineapples or to any of the excipients

Additional exclusion criteria

Pregnant and nursing women

Chemical or electrical burns

Age of burn injury $>48 \mathrm{~h}$

Regarding enzymatic debridement the preparation of the injuries is an extremely important aspect for facilitating the access of the active substances to the devitalized skin areas. The basic scrubbing is essential for achieving effective debriding, so patients have been introduced into the operating room after performing the necessary preclinical investigations, thus creating the premise of the rapid onset of enzyme treatment. Two hours before applying the active substance the lesions were covered with antibacterial substance and physiological serum in order to facilitate the hydration and penetration of proteolytic enzymes in the deep planes of the eschars $[8,48]$.
If the patient qualified for ED, sufficient analgesia was ensured by either timely administration of p.o./ i.v. pain medication or ultrasound-guided placement of brachial plexus nerve block by an anaesthesiologist [27]. Additional pain medication was given if needed. Some patients received the application under anaesthesia since the severity of their total burn injuries had required intubation and ongoing sedation. The duration of action of the proteolytic enzymes enriched with bromelain was 4 hours, that is the time necessary for the chemical processes underlying the selective lysis of the devitalized tissues. To facilitate the intimate contact between the active substance and the targeted 
area, impermeable sheets were used circumferentially delimited by the application of paraffin. An amount of $22 \mathrm{~g}$ of active gel was used at a surface area of about $100 \mathrm{~cm}^{2}$, thereby obtaining a continuous gel layer with thickness varying between 1.5 and $3 \mathrm{~mm}$. Removal of the dissolved eschar was accomplished by using a sterile metal scraper with atraumatic edges, thus avoiding damage to viable tissues. After the enzymatic debridement, a dressing with an antibacterial solution was applied, which was maintained for 2 hours.

In Standard of Care (SOC), depending on the quality of the affected tissues, the plastic surgeon decided whether the treatment will be continued using conservative treatment or surgical excision followed by split-thickness skin grafting.

In order to determine the possible changes during the coagulation process, the following blood test parameters were analysed and monitored: international normalized ratio (INR), prothrombin time (PT). These parameters were determined using Beckman Coulter AcT 5 Diff AL (Autoloader) and available commercial kits (Biolabo, France).

The applied methodology aimed for the evaluation of the enzymatic debridement rate, escharectomy rate and the possibility of extending the recommended body surface that can be treated by applying CPE-B in multiple stages.

The therapeutic protocol used for the second group of patients treated by surgical excision included: basic surgical scrubbing; subjective evaluation related to the depth of the wound performed by the surgeon; surgical excision of the lesion; skin grafting or conservative treatment.

In order to evaluate the degree of satisfaction related to each group the patients have assigned a grade for the medical treatment on a scale from 1 to 10,1 being the minimal value and 10 being the maximal value. Statistical analysis was performed by applying the t-Student test; $\mathrm{p}<0.05$ was considered significant.

\section{Results and Discussion}

Research results started with the patients' medical history that was investigated in order to determine each of the patients' status at admission (Table II), considering also the exclusion criteria (Table I).

Table II

Demographics and comorbidities related to the patients included in the study

\begin{tabular}{|c|c|c|c|c|c|}
\hline Demographics & Group 1 & Group 2 & Comorbidities & Group 1 & Group 2 \\
\hline Age (y; SD) & $49.3(10.80)$ & $52.1(9.70)$ & Inhalatory lesions (n; \%) & $11(9.16 \%)$ & $14(10.29 \%)$ \\
\hline BMI $\left(\mathrm{kg} / \mathrm{m}^{2} ; \mathrm{SD}\right)$ & $27.6(3.80)$ & $25.8(4.10)$ & Arterial hypertension (n; \%) & $32(26.66 \%)$ & $43(31.62 \%)$ \\
\hline $\operatorname{Men}(n ; \%)$ & $76(63.33 \%)$ & $84(61.76 \%)$ & Congestive heart failure $(\mathrm{n} ; \%)$ & $28(23.33 \%)$ & $25(18.38 \%)$ \\
\hline Urban dwelling (n; \%) & $85(70.83 \%)$ & $92(67.65 \%)$ & Coagulopathy (n; \%) & $8(6.66 \%)$ & $6(4.41 \%)$ \\
\hline Higher education (n; \%) & $41(34.16 \%)$ & $55(40.44 \%)$ & Diabetes mellitus (n; \%) & $15(12.50 \%)$ & $17(12.50 \%)$ \\
\hline Smoking (n; \%) & $43(35.83 \%)$ & $48(35.29 \%)$ & Dyslipidaemia (n; \%) & $18(15.00 \%)$ & $21(15.44 \%)$ \\
\hline Inter-hospital transfer & $73(60.83 \%)$ & $81(59.56 \%)$ & HBV (n; \%) & $2(1.66 \%)$ & $1(0.74 \%)$ \\
\hline
\end{tabular}

Note: $\mathrm{SD}=$ standard deviation

The average TBSA values for Group 1 and Group 2 were $32.06 \% \pm 17.90$, respectively $38.03 \% \pm 13.50$. Table III summarizes the data related to TBSA and the treatment used during the hospital stay for the studied groups.

120 patients included in Group 1 (76 men and 44 women) with different location burns proved to be eligible for achieving a complete initial debridement (Figure 1): 106 patients had lesions in the hand and upper limb region; 40 patients had both upper and lower limb burns; in 30 of the cases circumferential lesions were observed rising the problem of elevated intra-compartmental pressure; 5 patients suffered from burn injuries in the facial region.

Table III

Specifications related to TBSA and the type of treatment

\begin{tabular}{lrr}
\hline & \multicolumn{1}{c}{ Group 1 } & \multicolumn{1}{c}{ Group 2 } \\
\hline Average \% TBSA burns (range) & $32.06 \%(2-78)$ & $38.03 \%(3-90)$ \\
Average stay (days) (ICU+SICU) (range) & $33(26-38)$ & $41(5-93)$ \\
Average ICU stay (days) (range) & $7(3-9)$ & $10(2-25)$ \\
Average SICU stay (days) (range) & $26(11-32)$ & $31(7-85)$ \\
Escharotomy (unit $\times$ number of patients) & $2 \times 2$ & $5 \times 2$ \\
Autograft (unit $\times$ number of patients) & $1 \times 88$ & $1 \times 136$ \\
Blood Transfusion & $8.33 \%$ & $19.3 \%$ \\
CPE-B units consumed per patient & $1.4 \pm 0.5$ & 0 \\
\hline
\end{tabular}

ICU: intensive care unit; SICU: subintensive care unit; TBSA: total body surface area 


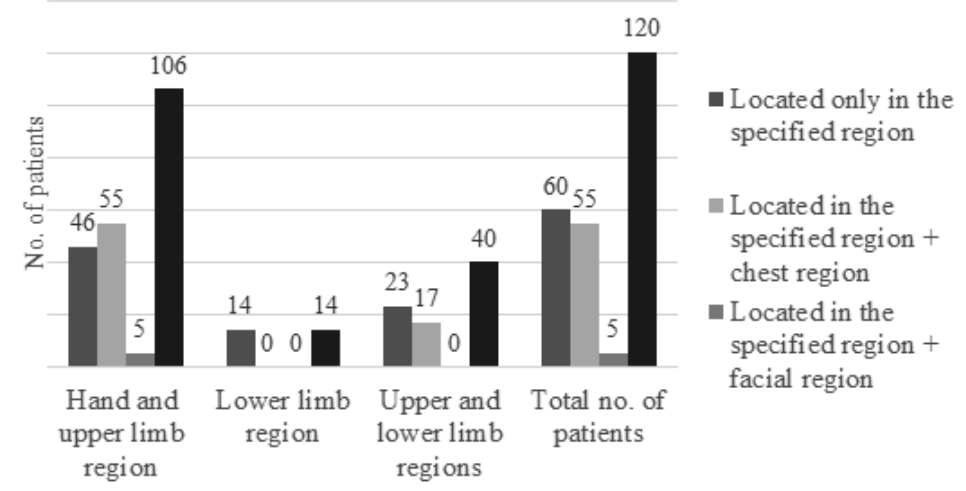

Figure 1.

Burn wounds topography depending on body region in Group 1

Regarding the associated injuries encountered in Group 1,55 of the patients that have suffered from burn injuries in the limb regions have also encountered lesions in the chest region, while only 4 patients have suffered from burn wounds in both limb and facial regions.

In order to establish the advantages and disadvantages of enzymatic debridement, the results of the study were compared with data gathered from a control group, patients treated by surgical excision (Group 2). The $2^{\text {nd }}$ Group included 136 patients $(84$ men and
52 women) with different location burns proved to be eligible for achieving a complete initial debridement: 114 patients had lesions in the hand and upper limb region; 52 patients had both upper and lower limb burns; in 32 of the cases circumferential lesions were observed rising the problem of elevated intracompartmental pressure; 10 patients suffered from burn injuries in the facial region.

In order to have an overlook on the localization of the burn wounds, Table IV presents the data gathered from each group of patients.

Table IV

Localization of burn wounds suffered by the patients included in the study

\begin{tabular}{lcccccccc}
\hline & $\begin{array}{r}\text { No. of patients/ } \\
\text { associated } \\
\text { region }\end{array}$ & $\begin{array}{c}\text { Both } \\
\text { limbs }+ \\
\text { chest } \\
\text { region }\end{array}$ & $\begin{array}{c}\text { Left } \\
\text { limb }+ \\
\text { chest } \\
\text { region }\end{array}$ & $\begin{array}{c}\text { Right } \\
\text { limb }+ \\
\text { chest } \\
\text { region }\end{array}$ & $\begin{array}{c}\text { Both } \\
\text { limbs }+ \\
\text { facial } \\
\text { region }\end{array}$ & $\begin{array}{c}\text { Left limb }+ \\
\text { facial region }\end{array}$ & $\begin{array}{c}\text { Right limb }+ \\
\text { facial region }\end{array}$ & $\begin{array}{c}\text { Only in the } \\
\text { specified } \\
\text { region }\end{array}$ \\
\hline Hand and upper & Group 1 & 32 & 16 & 7 & 1 & 1 & 3 & 46 \\
limb region & Group 2 & 36 & 15 & 25 & 5 & 1 & 4 & 28 \\
Lower limb & Group 1 & 0 & 0 & 0 & 0 & 0 & 0 & 14 \\
region & Group 2 & 0 & 0 & 0 & 0 & 0 & 0 & 22 \\
Upper and lower & Group 1 & 7 & 8 & 2 & 0 & 0 & 0 & 23 \\
limb regions & Group 2 & 15 & 7 & 10 & 0 & 0 & 0 & 20 \\
Total no. of & Group 1 & 32 & 16 & 7 & 1 & 1 & 3 & 60 \\
patients & Group 2 & 36 & 15 & 25 & 5 & 1 & 4 & 50 \\
\hline
\end{tabular}

The overall rate of enzymatic debridement was estimated with a median value of $93 \%(p<0.05)$, the decrease being largely influenced by cases that had been transferred from other healthcare facilities and have received late enzymatic debridement treatment (more than 72 hours after the trauma) (Table V).

Table V

Rate of enzymatic debridement by region

\begin{tabular}{|c|c|c|c|c|c|c|}
\hline $\begin{array}{rr}\begin{array}{r}\text { Enzymatic debridement rate/ } \\
\text { associated region } \\
\text { Body region }\end{array} \\
\end{array}$ & $\begin{array}{c}\text { Hand and upper } \\
\text { limb region } \\
(\%) \\
\end{array}$ & $\begin{array}{l}\text { Lower limb } \\
\text { region } \\
(\%) \\
\end{array}$ & $\begin{array}{l}\text { Average } \\
\text { rate } \\
(\%) \\
\end{array}$ & $\begin{array}{c}\text { Average TI } \\
\text { (hours) }\end{array}$ & SD & $\begin{array}{c}p \\
\text { (value) }\end{array}$ \\
\hline Both limbs + chest region & 97.00 & 93.00 & 95.00 & 29.97 & 22.75 & 0.0001 \\
\hline Left $\operatorname{limb}+$ chest region & 94.00 & 92.00 & 93.00 & 42.38 & 25.95 & 0.0007 \\
\hline Right limb + chest region & 91.50 & 93.00 & 92.25 & 54.14 & 26.55 & 0.045 \\
\hline Both limbs + facial region & 90.00 & 89.00 & 89.50 & 46.00 & N/A & $\mathrm{N} / \mathrm{A}$ \\
\hline Left $\operatorname{limb}+$ facial region & 92.00 & 91.00 & 91.50 & 24.00 & N/A & N/A \\
\hline Right limb + facial region & 90.50 & 91.00 & 90.75 & 62.66 & 34.95 & 0.2090 \\
\hline Average rate for associated regions & 92.50 & 91.50 & 92.00 & 43.19 & - & - \\
\hline Only in the specified region & 95.00 & 93.00 & 94.00 & 40.12 & 27.71 & 0.0030 \\
\hline Average rate for all regions & 93.75 & 92.25 & 93.00 & 41.66 & - & - \\
\hline
\end{tabular}


Patients who were treated less than 24 hours after the trauma have had an enzymatic debridement rate of over $96 \%$.

For each patient an average of $1.4 \pm 0.5$ applications were used during the treatment. Following the enzymatic debridement, 88 patients underwent surgical procedures including skin grafting.

Regarding the duration of hospitalization: patients treated with CPE-B stayed on an average 7 days in the ICU and 33 days in the SICU, whereas in the case of patients from Group 2 (SOC) the patients state on an average 10 days in the ICU and 41 days in the SICU; 2 patients in the CPE-B group underwent escharectomies, whereas in the Group 2, 5 escharectomies were performed; eighty-eight patients in the studied group underwent autograft surgery, whereas in the SOC group 136 autograft surgeries were conducted; $8.33 \%$ of patients in the CPE-B group required transfusion with 1 unit of blood (RBC) each, whereas $19.3 \%$ of the patients in the Group 2 required transfusion.
The research results showed that the introduction of modern enzymatic debridement techniques has been an important step in reducing hospitalization time, reducing trauma associated with surgery, and improving long-term results. In particular, the costs of hospitalization in the intensive care unit (ICU) and subintensive care unit (SICU) concerned the following four cost components: diagnostics (medical imaging and laboratory services), consumables (drugs, fluids, and disposables), hotel and nutrition, and labour (specialists, nurses, and consulted specialists such as medical specialists, pharmacists, laboratory technicians). Management of burn patients is notoriously expensive in terms of patient hospitalization time, surgical procedures, transfusion, dressings, and other accessory therapeutic measures, and dedicated ICU personnel and related costs. Table VI demonstrates the assessment of budget expenses and the cost comparison between the CPE-B and SOC groups according to the specialized literature [18].

Table VI

Cost analysis and relative and total savings. SOC versus CPE-B [18]

\begin{tabular}{lccccccc}
\hline & SOC & CPE-B & CPE-B saving & 95\% CI costs SOC & 95\% CI costs CPE-B \\
\hline $\begin{array}{l}\text { ICU stay cost } \\
\text { (each 1325 euros) }\end{array}$ & 102025 & 83475 & 18550 & 8082.5 & 12190 & 6757.5 & 9937.5 \\
$\begin{array}{l}\text { SICU stay cost } \\
\text { (each 475 euros) }\end{array}$ & 136800 & 118275 & 18525 & 12682.5 & 14677.5 & 11020 & 12635 \\
$\begin{array}{l}\text { Escharectomy cost } \\
\text { (each 1675 euros) }\end{array}$ & 21775 & 0 & 21775 & 1591.25 & 2747 & 0 & 0 \\
$\begin{array}{l}\text { Autograft cost } \\
\text { (each 12414 euros) }\end{array}$ & 124140 & 74484 & 49656 & 12414 & 12414 & 2855.22 & 11917.44 \\
$\begin{array}{l}\text { Blood transfusion } \\
\text { (each 208 euros) }\end{array}$ & 3744 & 1040 & 2704 & 145.6 & 395.2 & 24.96 & 187.2 \\
$\begin{array}{l}\text { Gross CPE-B saving } \\
\text { CPE-B cost }\end{array}$ & - & - & 111210 & - & - & - & - \\
\hline Totals & - & 57910 & - & - & - & - & - \\
\hline - standard of care; ICU - intensive care unit; SICU - subintensive care unit; CI - confidence interval & & & & & & \\
\hline
\end{tabular}

The development of therapeutic protocols focused on the preservation of viable tissues and those in distress, has brought an important contribution to the effective treatment of severe and large burns. The results indicated that enzymatic debridement is an effective therapeutic method for saving viable tissues in the immediate vicinity of eschars and deep burns. The importance of this principle lies in the fact that burned patients are often systemically unbalanced; therefore achieving metabolic stability is as important as performing surgical treatment in these cases. Regarding the enzymatic debridement in the chest region, improving the scar tissue in the mammary region could set the premises for a successful breast reconstruction [4].

Another result related to enzymatic debridement is the ability to reduce the intra-compartmental pressure obtained by relaxing the tension from the circular burn injuries. Reducing the need for escharectomy in these patients translates into lowering haemorrhagic risk and also reducing protein losses, speeding up the healing process $[12,33]$.

From the 30 patients that have suffered elevated intracompartmental pressure, escharectomy was required only in case of 2 patients $(6.66 \%)$, while 28 patients $(93.33 \%)$ have benefited from reduced intracompartmental pressure as a result of the treatment with CPE-B.

The results of the analysis showed that hospitalization time is shorter in case of enzymatic debridement (33 days in the ICU and SICU) compared to the classical surgical treatment (41 days in the ICU and SICU). Given the high costs of ICU the reduced time spent by the patients within this unit (7 days compared to 10 days for classical treatment) is an important advantage of the burns treatment using enzymatic debridement.

Regarding the degree of satisfaction the patients included in Group 1 have had higher values (8.95) compared to Group 2 (8.32). These results could be 
FARMACIA, 2019, Vol. 67, 3

determined by the reduced hospitalization and ICU time, the reduced number of scars as a consequence of not performing escharectomies, the improvement of the quality of the scars and accelerated wound healing.

Regarding abnormalities related to coagulation times in $4.17 \%$ of the cases modifications were encountered that could be associated with the use of CPE-B, the average value increase of INR over 1.15 being 0.76 , while reaching a maximum value of 2.30 . Regarding PT the average value increase was 1.08 and the maximum value that was determined was 17.42 .

Bromelain is considered to be non-toxic and may be used at daily doses of 200 to $2,000 \mathrm{mg} / \mathrm{kg}$, for prolonged periods of time [34, 39]. The degree to which bromelain and its components are absorbed and retain function still remains to be elucidated, but studies have suggested that oral administration of this proteolytically active pineapple extract is absorbed into the intestines and remains biologically active with a half-life of $\sim 6-9 \mathrm{~h}$ and plasma concentration reaching as much as $5,000 \mathrm{pg} / \mathrm{mL}$ by $48 \mathrm{~h}$ after oral multi-dosing of $3 \mathrm{~g} /$ day [7]. Reports from preliminary clinical studies have indicated the potential safety and efficacy of bromelain-based enzymatic debridement in chronic wounds [46] and deep burn injuries [42].

Critical factors of burn diagnosis are the determination of the percentage of Total Body Surface Area (\% TBSA) burned and the assessment of burn depth. The percent of TBSA can be roughly estimated by using the rule of nines or by the patient's hand, which approximates $1 \%$ of the TBSA [2, 52]. Burns are classified according to the depth of the injury as superficial (first degree), (superficial) partial thickness (second degree), or full thickness deep (third degree) burns [50]. The larger the percentage of TBSA involved and the deeper the burn, the worse the prognosis and the higher the acute treatment costs. After the burned patient is admitted in the burn unit, the wounds are cleaned with soap and sterile water, debris are removed, and an initial extent and depth of the burn is established. An essential primary step in the acute treatment of deep burn wounds is removal of burn eschar. The efficacy of eschar removal has a great impact on post-debridement wound care and the overall outcome of a burn patient [51]. Surgical debridement followed by autografting is the standard of care (SOC) for deep burns and represents an invasive surgical procedure. Post-burn injuries are complex medical-surgical cases requiring impressive logistical and financial resources, the formation of highly specialized surgeons in the treatment of these lesions being a time-consuming process [28, 44]. The infrastructure needed to treat these patients is extremely expensive; therefore budgets for these significant resources are allocated within national programs by the specialized state institutions.
Enzymatic debridement by CPE-B is a new nonsurgical tool for selective removal of the eschar and is indicated for the treatment of adults with deep partial and/or full thickness burns.

There is an increasing trend associated with the use of enzymatic debridement as a form of non-operative burn eschar removal. Debridement using bromelainenhanced proteolytic enzymes is a recent therapeutic option, proposing a solid alternative $[23,44]$ to the classical surgical excision of burn injuries. Bromelain applied as a cream ( $35 \%$ bromelain in a lipid base) can be beneficial for debridement of necrotic tissue and acceleration of healing. The latest research proved that bromelain contains escharase which is responsible for this e ect. Escharase is nonproteolytic and has no hydrolytic enzyme activity against normal protein substrate or various glycosaminoglycan substrates. Its activity varies greatly with di erent preparations [24]. Scientific literature shows that, during enzymatic debridement using CPE-B, keratinocytes and fibroblasts are directly affected by proteolytic enzymes, however cellular selectivity with preservation of macrophage viability [40] can be a determining factor in accelerating the local healing process. According to Di Lonardo et al. in 2018 [13], among the three areas characteristic of burn injuries, the highest proteolytic enzyme activity rate was identified at the level of the necrosis area, the stasis and the hyperaemic areas being affected to a much lesser extent by the lysis process caused by the application of CPE-B. Therefore, effective wound management after enzymatic debridement by applying bromelain is better than surgical debridement as surgical incision is painful, nonselective and exposes the patients to the risk of repeated anaesthesia and significant bleeding $[25,35,45]$. Also, the management of the burned patient is very complex involving multiple metabolic changes and imbalances with coagulation abnormality resulting in significant volumetric loss [11].

The cost of treating patients with burns is extremely high: multiple surgeries, treatment in the intensive care unit and specific infrastructure are just some of the elements that require important financial resources [27].

Complex traumas at the level of the cephalic region require the development of a complex therapeutic algorithm, which may involve the use of local and free tissue transfer flaps $[19,31]$ in combination with enzymatic debridement, these being the situations where the combination of the two techniques provides the best results.

A comparative analysis between the results of the study and the current state of knowledge was performed focusing on the efficiency of the enzymatic debridement. A study by Schulz et al. (2017) presents similar results, indicating a $90 \%$ efficiency rate associated 
with an overrated appreciation related to the severity of the lesion [43].

The results of the current study are also comparable when it comes to the treatment of lesions in the upper and lower limbs using CPE-B, confirming the increased efficacy of this method due to the selective debridement which improves the quality of the scars. The comparative analysis also involves other materials dedicated to the understanding of the enzymatic treatment in patients with extensive burns showing that this type of technique can be used to treat burns of large dimensions while performing a staged protocol that does not expose the patient to additional risks. A research conducted by Shoham et al. in 2017 confirms that the approach involving a staged protocol does not cause cumulative side effects. Regarding the adverse effects associated with this type of treatment, no severe complications were identified in the present study, moderate changes related to the coagulation times based on the values of INR and PT being observed in the initial stages of the enzymatic debridement [47].

The treatment of burns using enzymatic debridement with CPE-B was initially addressed to lesions not exceeding $15 \%$ of the body surface, but this study results show that the use of the technique in multiple stages is a feasible therapeutic option that can contribute to reducing the hospitalization time in patients with complex burns involving over $50 \%$ of the body surface (Figure 2), in regard with burn mass casualty incidents.

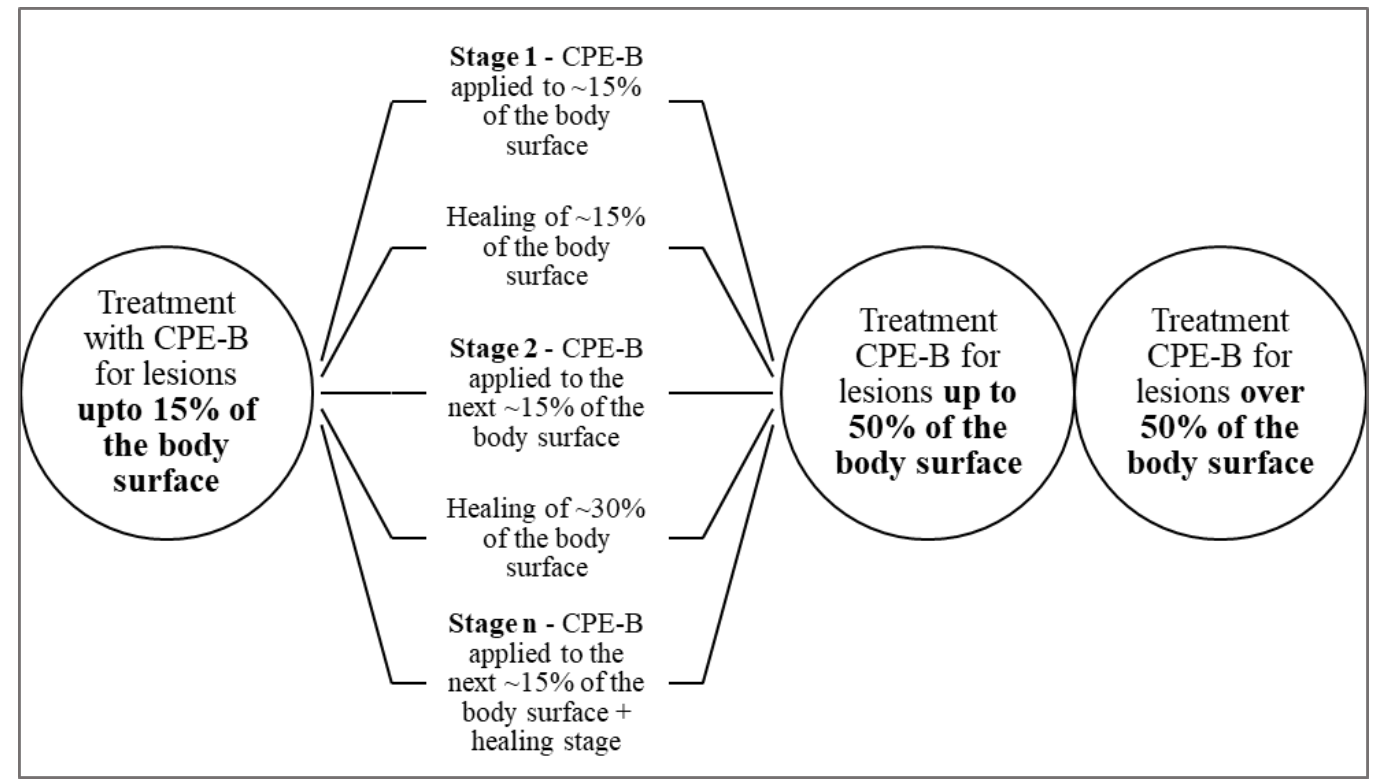

Figure 2.

Staged CPE-B treatment

For each stage of the treatment, the concentrate enriched with bromelain is applied to only $15 \%$ of the body surface, this method being essential in order to facilitate the continued enzymatic debridement in patients with extensive burns.

Postoperative recovery is an extremely important aspect in terms of rehabilitation and socio-professional integration of these patients. Pathological scarring is a negative prognostic element that requires special attention and requires the development of therapeutic protocols focused on reducing the incidence and severity of this complication.

Regarding enzymatic debridement, the tissue selectivity of this technique is the main factor contributing to reducing the incidence of pathological scarring as well as accelerating the posttraumatic recovery rate, significantly reducing the rate of repeated surgical interventions on retractile scars located at the joints.

\section{Conclusions}

Enzymatic debridement using CPE-B is a solid therapeutic alternative to the classical surgical treatment in patients who have suffered burn injuries that cover up to $15 \%$ of the body surface. The combination of enzymatic debridement with classical surgical treatment is a good therapeutic option for patients who have suffered burn injuries exceeding $15 \%$ of the body surface.

By performing enzymatic debridement with CPE-B, an important advantage is the reduction of unnecessary tissue loss caused by the subjective assessment of the depth of the lesion characteristic of the classical surgical approach. Product-specific tissue selectivity is a great advantage in reducing the systemic trauma associated with surgery.

This study shows that the use of CPE-B is associated with reduced hospitalization time, improvement of the appearance and physiological characteristics of 
post-burn scars, while also having an important impact on the functionality of the affected anatomical structures. The present research may bring a contribution to further studies related to the effects of including CPE-B in the therapeutic protocol in patients with intermediate and severe burns.

\section{Conflict of Interest}

The authors declared no conflict of interests.

\section{References}

1. Akhtar N, Abdel-Rehim S, Rodrigues J, Brooks P, The use of larvae therapy to debride full thickness burns in the anaesthetically unfit patient: The Nottingham experience. Burns, 2011; 37(6): 44-49.

2. Arturson G, Pathophysiology of the burn wound. Ann Chir Gynaecol., 1980; 69(5): 178-190.

3. Bartholomew DP, Paull RE, Rohrbach KG, The Pineapple: Botany, Production and Uses, CABI Publishing: Wallingford-UK, 2003.

4. Bejinariu CG, Apostolescu I, Marinescu S, Treatment of postcombustion scars of the breast - Case presentation. Rom J Med Pract., 2019; 14(1): 4851, (available in Romanian).

5. Bejinariu CG, Marinescu S, Giuglea C, Study on breast reconstruction after mastectomy in diabetic patients. Rom Med J., 2019; LXVI(1): 33-37, (available in Romanian).

6. Berner JE, Keckes D, Pywel M, Dheansa B, Limitations to the use of bromelain-based enzymatic debridement (CPE-B) for treating diabetic foot burns: a case series of disappointing results. Scars Burn Heal, 2018; 4: 1-7.

7. Castell JV, Friedrich G, Kuhn CS, Poppe GE, Intestinal absorption of undegraded proteins in men: presence of bromelain in plasma after oral intake. Am J Physiol., 1997; 273: G139-146.

8. Cherubino M, Pellegatta I, Sallam D, Pulerà E, Valdatta L, Enzymatic debridement after mobile phone explosion: a case report. Ann Burns Fire Disast., 2016; 28: 273-275.

9. Choi M, Panthaki ZJ, Tangential excision of burn wounds. J Craniofac Surg., 2008; 19(4): 1056-1060.

10. Cordts T, Horter J, Vogelpohl J, Kremer T, Kneser U, Hernekamp JF, Enzymatic debridement for the treatment of severely burned upper extremities early single center experiences. BMC Dermatol., 2016; 16: 8: 1-7.

11. Desai MH, Herndon DN, Broemeling L, Barrow RE, Nichols RJ Jr, Rutan RL, Early burn wound excision significantly reduces blood loss. Ann Surg., 1990; 211(6): 753-762.

12. Di Castri A, Quarta L, Mataro I, Riccardi F, Pezone G, Giordano L, Shoham Y, Rosenberg L, Caleffi E, The entity of thermal-crush-avulsion hand injury (hot-press roller burns) treated with fast acting debriding enzymes $\left(\right.$ Nexobrid $\left.^{\circledR}\right)$ : literature review and report of first case. Ann Burns Fire Disast., 2018; 31(1): 31-34.

13. Di Lonardo A, Nardini V, De Rosa M, Enzymatic escharolysis with NexoBrid on partial thickness burn wounds: pre- and post-debridement histological assessment. Ann Burns Fire Disast., 2018; 31(1): 23-27.

14. Dubey VK, Pande M, Singh BK, Jagannadham MV, Papain-like proteases: applications of their inhibitors. Afr J Biotech., 2007; 6(9): 1077-1086.

15. Duteille F, Perrot $P$, Management of $2^{\text {nd }}$-degree facial burns using the Versajet ${ }^{\mathbb{R}}$ hydrosurgery system and xenograft: A prospective evaluation of 20 cases. Burns, 2012; 38(5): 724-729.

16. Feijoo-Siota L, Villa TG, Native and Biotechnologically engineered Plant Proteases with Industrial applications. J Food Bioproc Tech., 2010; 4: 1066-1088.

17. Fu X, Wang S, Li L, Zhou I, The clinical evaluation of the effects of a new collagenase ointment (Iruxol mono) on debridement and wound healing in the burn wounds. Chin Med Sci J., 2000; 15(4): 200.

18. Giudice G, Filoni A, Maggio G, Bonamonte D, Vestita M, Cost Analysis of a Novel Enzymatic Debriding Agent for Management of Burn Wounds. Biomed Res Int., 2017; 2017: 9567498: 1-5.

19. Giuglea C, Florescu IP, Marinescu S, Lascar I, Tissue transplantation in face reconstruction. Chirurgia (Bucharest), 2011; 106(6): 789-798.

20. Grigorovici A., Cherciu MS, Popescu CM, Ciobanu Apostol DG, Preda C, Călin A, Aelenei P, Efficacy and safety of Regen-Sil ${ }^{\circledR}$ in post-operative scars management. Farmacia, 2017; 65(1): 29-39.

21. Gurfinkel R, Rosenberg L, Cohen S, Histological assessment of tangentially excised burn eschars. Can J Plast Surg., 2010; 18: e33-36.

22. Hale LP, Greer PK, Trinh CT, James CL, Proteinase Activity and Stability of Natural Bromelain Preparations. Int Immunopharmac., 2005; 5: 783-793.

23. Hitched C, Citterio A, Hoeksema H, Koller J, Lehner M, Martinez JR, Monstrey S, Murray A, Plock JA, Sander F, Schulz A, Ziegler B, Kneser U, Eschar removal by bromelain based enzymatic debridement (NexoBrid) in burns: An European consensus. Burns, 2017; 43(8): 1640-1653.

24. Houck JC, Chang CM, Klein G, Isolation of an e ective debriding agent from the stems of pineapple plants. Int J Tissue React., 1983; 5(2): 125-134.

25. Hu W, Wang AM, Wu SY, Debriding e ect of bromelain on firearm wounds in pigs. $J$ Trauma, 2011; 71(4): 966-972.

26. Kelly GS, Bromelain: A Literature Review and Discussion of its Therapeutic Applications. Alt Med Rev., 1996; 1(4): 243-257.

27. Kern MA, von Depka N, Schackert C, Henkel W, Hirche CR, Enzymatic burn wound debridement with Nexobrid ${ }^{\circledR}$ : Cost simulations and investigations on cost efficiency. Gesundh ökon Qual manag, 2018; 23(01): 21-28.

28. Krieger Y, Rubin G, Schulz A, Rosenberg N, Levi A, Singer AJ, Rosenberg L, Shoham Y, Bromelain-based enzymatic debridement and minimal invasive modality (mim) care of deeply burned hands. Ann Burns Fire Disast., 2017; 43: 1233-1243.

29. Langer V, Bhandari PS, Rajagopalan S, Mukherjee MK, Enzymatic debridement of large burn wounds with papain-urea: Is it safe?. Med J Armed Forces Ind., 2013; 69(2): 144-150. 
30. Leary D, Vierros M, Hamon G, Arico S, Monagle C, Marine genetic resources: a review of scientific and commercial interest. Mar Policy, 2009; 33: 183-194.

31. Marinescu S, Florescu I-P, Giuglea C, Lascăr I, Free tissue transfer in hand surgery-essential step in hand transplantation, Chirurgia (Bucharest), 2012; 107(1): 79-88.

32. Marinescu SA, Bejinariu CG, Giuglea C, Research related to Breast Implant-associated Anaplastic Large Cell Lymphoma and its influence on the decision-making process related to reconstructive techniques, Mat. Plast., 2019; 56(1): 229-234.

33. Mataro I, Giudice G, D’Alessio R, Maggio G, Vestita M, The use of NexobridTM, in debriding chronic ulcers: a preliminary observational study. Ann Burns Fire Disast., 2018; 31: 109-112.

34. Maurer HR, Bromelain: Biochemistry, Pharmacology and Medical Uses. Cell Mol Life Sci., 2001; 58: 1234-1245.

35. Miller JG, Carruthers HR, Burd DAR, A algorithmic approach to the management of cutaneous burns. Burns, 1992; 18(3): 200-211.

36. Mitsukawa N, Satoh K, Hosaka Y, Hemostasis by means of a cautery knife equipped with an air spray for burns over a large area. Burns, 2006; 32(6): 695-697.

37. Namias N, Varela E, Varas R, Quintana O, Ward G, Biodebridement: A Case Report of Maggot Therapy for Limb Salvage After Fourth-Degree Burns. $J$ Burn Care Rehabil., 2000; 21(3): 254-257.

38. Özcan C, Ergün O, Çelik A, Çördük N, Özok G, Enzymatic debridement of burn wound with collagenase in children with partial-thickness burns. Burns, 2002; 28(8): 791-794.

39. Rigueros Springford L, Creasy H, Cubison T, Dheansa $\mathrm{B}$, A novel technique of NexoBridTM application to burns on the hands. Burns, 2017; 43: 1132-1133.

40. Rosenberg L, Krieger Y, Bogdanov-Berezovski A, Silberstein E, Shoham Y, Singer AJ, A novel rapid and selective enzymatic debridement agent for burn wound management: a multi-center RCT. Burns, 2014; 40(3): 466-474.

41. Schulz A, Fuchs PC, Hans N, Opländer C, Valdez LB, Schiefer JL, Inhibition of Bromelain Activity during Enzymatic Debridement of Burn Wounds Pretreated with Frequently Used Products. J Burn Care Res., 2018; 39: 413-422.

42. Schulz A, Fuchs PC, Rothermundt I, Hoffmann A, Rosenberg L, Shoham Y, Enzymatic debridement of deeply burned faces: Healing and early scarring based on tissue preservation compared to traditional surgical debridement. Burns, 2017; 43: 1233-1243.

43. Schulz A, Perbix W, Shoham Y, Daali S, Charalampaki C, Fuchs PC, Schiefer J, Our initial learning curve in the enzymatic debridement of severely burned hands Management and pit falls of initial treatments and our development of a post debridement wound treatment algorithm. Burns, 2017; 43: 326-336.

44. Schulz A, Ribitsch B, Fuchs PC, Lipensky A, Schiefer JL, Treatment of Genital Burn Injuries. Adv Skin Wounds Care, 2018; 314-321.

45. Sheridan RL, Tompkins RG, Burke JF, Management of burn wounds with prompt excision and immediate closure. J Int Care Med., 1994; 237: 68-75.

46. Shoham Y, Krieger Y, Tamir E, Silberstein E, BogdanovBerezovsky A, Haik J, Rosenberg L, Bromelainbased enzymatic debridement of chronic wounds: A preliminary report. Int Wound, 2018; 15: 769-775.

47. Shoham Y, Rosenberg L, Ascula E, Keren D, Klinger E, Krieger Y, Silberstein E, Bogdanov-Berezovsky A, Nexobrid ${ }^{\circledR}$ in large burns - results of a pharmacokinetic study. Proceedings of the $17^{\text {th }}$ European Burns Association Congress, Barcelona, Spain, September 2017, www.morressier.com/article/nexobrid-largeburns--results-pharmacokinetic-study/594bbebfd 4 62b8028d893f5f.

48. Udeanu D, Albu Kaya MG, Ghica MV, Marin Ș, Marin MM, Kaya DA, Popa L, Dinu-Pîrvu C, Antiinflammatory drug-loaded biopolymeric spongious matrices with therapeutic perspectives in burns treatment. Farmacia, 2018; 66(5): 783-790.

49. Xiao-Wu W, Herndon DN, Spies M, Sanford AP, Wolf SE, Effects of Delayed Wound Excision and Grafting in Severely Burned Children. Arch Surg., 2002; 137(9): 1049-1054.

50. ***American Burn Association White Paper. Surgical Management of the Burn Wound and Use of Skin Substitutes. www. ucdenver.edu/academics/colleges/ medicalschool/departments/surgery/divisions/GITE S/burn/Documents/American\%20Burn\%20Associa tion\%20White\%20Paper.pdf; $\neg$ Zugriff:-23.06.2015.

51. ***AWMF. S1-Leitlinie Verbrennungsmedizin/ Thermische und chemische Verletzungen. AWMFLeitlinien-Register Nr 044/001; 2010.

52. ***European Burns Association. European Practice Guidelines for Burn Care. http://euroburn.org/wpcontent/uploads/Documents/Guidelines/EBA _Guidelines_-_2013_Vienna_Edition.pdf $\neg$ Zugriff:23.06.2015.

53. ***MediWound Germany GmbH. NexoBrid $2 \mathrm{~g}$ Powder and Gel for Gel - Summary of Product Characteristics. 2014.

54. ***The Order of Ministry of Health no. 12/2016, www.ms.ro/wp-content/uploads/2016/12/ordinarsuri.pdf, (available in Romanian). 